\title{
PENGEMBANGAN SUPLEMEN BAHAN AJAR DIGITAL PADA MATA PELAJARAN GEOGRAFI DENGAN TOPIK BAHASAN SUMBER DAYA LAUT BERBASIS KEARIFAN LOKAL
}

\author{
Ika Handayani Nurani Putri*, Ulfatush Sholihah*, Era Megawati Handayani **, \\ Sumarmi* \\ * (Pendidikan Geografi, Fakultas Ilmu Sosial, Universitas Negeri Malang) \\ ** (Pendidikan Akuntansi, Fakultas Ilmu Sosial, Universitas Negeri Malang)
}

\section{INFO ARTIKEL \\ Riwayat Artikel:}

Diterima: 25-1-2018

Disetujui: 19-4-2018

\section{Kata kunci:}

suplemen bahan ajar, geografi, sumber daya laut, kearifan lokal

\author{
Alamat Korespondensi: \\ Ika Handayani Nurani Putri \\ Pendidikan Geografi \\ Universitas Negeri Malang \\ Jl. Semarang No. 5 Malang \\ E-mail: ikahandayani007@gmail.com
}

\begin{abstract}
ABSTRAK
Abstrak: Indonesia memiliki potensi sumber daya laut yang tinggi. Potensi tersebut menyebabkan pemanfaatan berlebih, yang berdampak pada degradasi sumber daya laut. Oleh karena itu, perlu adanya cara pemanfaatan sumber daya laut yang ramah lingkungan. Kearifan lokal Jaring Tarik merupakan cara tradisional nelayan untuk menangkap ikan yang ramah lingkungan, namun mulai ditinggalkan. Pelestarian kearifan lokal yang mampu menjaga keberlanjutan sumber daya laut dapat dilakukan melalui dunia pendidikan dengan suplemen bahan ajar yang memuat kearifan dalam pemanfaatan suber daya laut. Pengembangan suplemen bahan ajar menerapkan model Borg \& Gall. Tahapan pengembangan tersebut meliputi penelitian dan pengumpulan informasi, perencanaan, pengembangan draft produk awal, validasi, revisi produk, uji coba kelompok kecil, dan menghasilkan produk akhir. Produk akhir berupa suplemen bahan ajar digital dengan format EXE berukuran 500MB. Berdasarkan hasil validasi ahli materi, desain, dan bahasa diperoleh nilai 95\%, 90\%, dan 91,67\%. Hasil uji coba kelompok kecil guna mengetahui keterbacaan bahan ajar diperoleh nilai $88,08 \%$. Rata-rata yang diperoleh berdasarkan validasi dari para ahli dan berdasarkan uji coba kelompok kecil, mendapat presentase sebesar 91,19\% dengan kriteria layak.
\end{abstract}

\section{PENDAHULUAN}

Keberadaan wilayah laut yang meliputi hampir 2/3 luas teritorial negara menjadikan Indonesia memiliki potensi sumber daya laut yang tinggi.Sumber daya laut tersebut meliputi sumber daya yang dapat pulih seperti perikanan, hutan mangrove, terumbu karang, dan lainlain (Darsono, 1999). Sejalan dengan hal tersebut, menurut Kusumastanto (2003) produksi sumber daya yang dapat pulih berupa perikanan laut (tuna/cakalang, udang, demersal, pelagis kecil, dan lainnya) sekitar 4.948 .824 ton/tahun, dengan taksiran nilai US\$ 15.105.011.400, serta budidaya laut (rumput laut, ikan, dan kerang-kerangan serta mutiara) sebanyak 528.403 ton/tahun dengan taksiran nilai US\$ 567.080.000. 
Jurnal Pendidikan Geografi:

Kajian, Teori, dan Praktik dalam Bidang Pendidikan dan Ilmu Geografi

Tahun 23, Nomor 2, Jun 2018 , Hal 78-84

Potensi sumber daya laut yang melimpah menyebabkan pemanfaatannya meningkat hampir diseluruh wilayah Indonesia (Stanis, 2005). Wilayah pemanfaat sumber daya laut tersebut utamanya pada wilayah pesisir. Hal ini dikarenakan pada wilayah pesisir potensi sumber daya laut merupakan potensi utama. Potensi utama suatau wilayah merupakan acuan utama untuk dikembangkan (Sumarmi, 2012).

Pemanfaatan sumber daya laut guna memenuhi kebutuhan tanpa memperhatikan daya dukungnya menyebabkan degradasi sumber daya tersebut. Hal ini terlihat dari meningkatnya penangkapan ikan berlebih (over fishing) (Sholihin, dkk, 2013). Penangkapan berlebih dapat terjadi dalam bentuk growth over fishing dan recruitment overfishing (Froese, 2004).Gejala Growth overfishingterlihat dari ukuran ikan hasil tangkap yang semakin kecil. Hal ini dikarenakan ikan yang tertangkap masih di bawah umur panen. Recruitment overfishing dicirikan dengan menghilangnya individu baru secara mendadak sebagai dampak daripenangkapan induk potensial.

Berdasarkan penjabaran di atas dapat diketahui bahwa degradasi sumber daya laut terjadi akibat interaksi antara manusia dengan alam. Pemanfaatan sumber daya laut secara berlebih tanpa memperhatikan daya dukung sumber daya tersebut akan menyebabkan kerusakan. Menurut Stanis (2005) hal yang menyebabkan pemanfaatan sumber daya laut secara berlebihan tanpa melihat daya dukung lingkungan adalah pembangunan produksi perikanan didominasi oleh penerapan usaha efisiensi penangkapan dan penerapan teknologi, dibanding pendekatan yang mempromosikan cara-cara pemanfaatan dan pengelolaan yang berkelanjutan. Untuk itu perlu adanya cara pemanfaatan sumber daya laut yang ramah lingkungan sehingga keberlanjutan sumber daya tersebut dapat terjaga.

Cara pemanfaatan sumber daya laut yang ramah lingkungan guna menjaga keberlanjutan sumber daya laut sebenarnya telah diterapkan nenek moyang bangsa Indonesia. Sebelum adanya teknologi modern, bangsa Indonesia telah mengenal cara penangkapan ikan secara tradisional. Hal tersebut merupakan bagian dari pengetahuan lokal masyarakat untuk dapat bertahan hidup. Pengetahuan ini diwariskan secara turun temurun dalam jangka waktu yang lama dan menyatu dengan adat atau norma masyarakat setempat (Sumarmi, 2014). Oleh karenanya dikenal sebagai kearifan lokal.

Salah satu contoh kearifan lokal dalam pemanfaatan sumber daya laut ada pada masyarakat nelayan di Prigi, Trenggalek.Masyarakat nelayan di Pantai Prigi Trenggalek, Jawa Timur masih menerapkan cara tradisional dalam penangkapan ikan. Cara penangkapan ikan secara tradisional yang dilakukan dikenal dengan Jaring Tarik. Penangkapan ikan dengan Jaring Tarik tidak dapat dilakukan setiap saat. Cara ini sangat bergantung pada alam. Karena itu, cara ini dapat menjaga keberlanjutan sumber daya laut.

Jaring Tarik sebagai kearifan lokal mampu menjaga keberlanjutan sumber daya laut hingga kini. Sayangnya, seiring berkembangnya teknologi banyak masyarakat nelayan yang mulai meninggalkan metode ini. Masyarakat nelayan beralih menggunakan kapal bermesin yang mampu menempuh jarak jauh untuk menangkap ikan. Cara seperti ini dikhawatrikan mengancam keberlanjutan sumber daya laut. Oleh karena itu, perlu adanya usaha untuk melestarikan kearifan lokal Jaring Tarik.

Pelestarian kearifan lokal Jaring Tarik yang mampu menjaga keberlanjutan sumber daya laut dapat dilakukan melalui dunia pendidikan. Siswa sebagai generasi muda diperkenalkan dengan kearifan lokal yang ada pada masyarakat dalam memanfaatkan sumber daya laut. Untuk memperkenalkannya dapat dilakukan melalui suplemen bahan ajar yang memuat kearifan dalam pemanfaatan suber daya laut.

Suplemen bahan ajar yang memuat kearifan dalam pemanfaatan sumber daya laut dikemas dalam bentuk digital yang kreatif. Suplemen bahan ajar dalam bentuk digital ini dapat mempermudah publiasinya karena dapat diakses secara online. Suplemen bahan ajar 
Jurnal Pendidikan Geografi:

Kajian, Teori, dan Praktik dalam Bidang Pendidikan dan Ilmu Geografi

Tahun 23, Nomor 2, Jun 2018 , Hal 78-84

ini juga ditampilkan dalam bentuk yang kreatif melalui flipbook. Flipbook akan menjadikan pembaca seolah membaca buku konfensional karena dapat membolak-balik halaman sesuai keinginan.

\section{METODE}

Prosedur pengembangan bahan ajar yang mengacu model Borg dan Gall (1983). Pengembangan ini hanya akan dilakukan tujuh tahap. Tahap tersebut dapat dilihat pada gambar berikut.

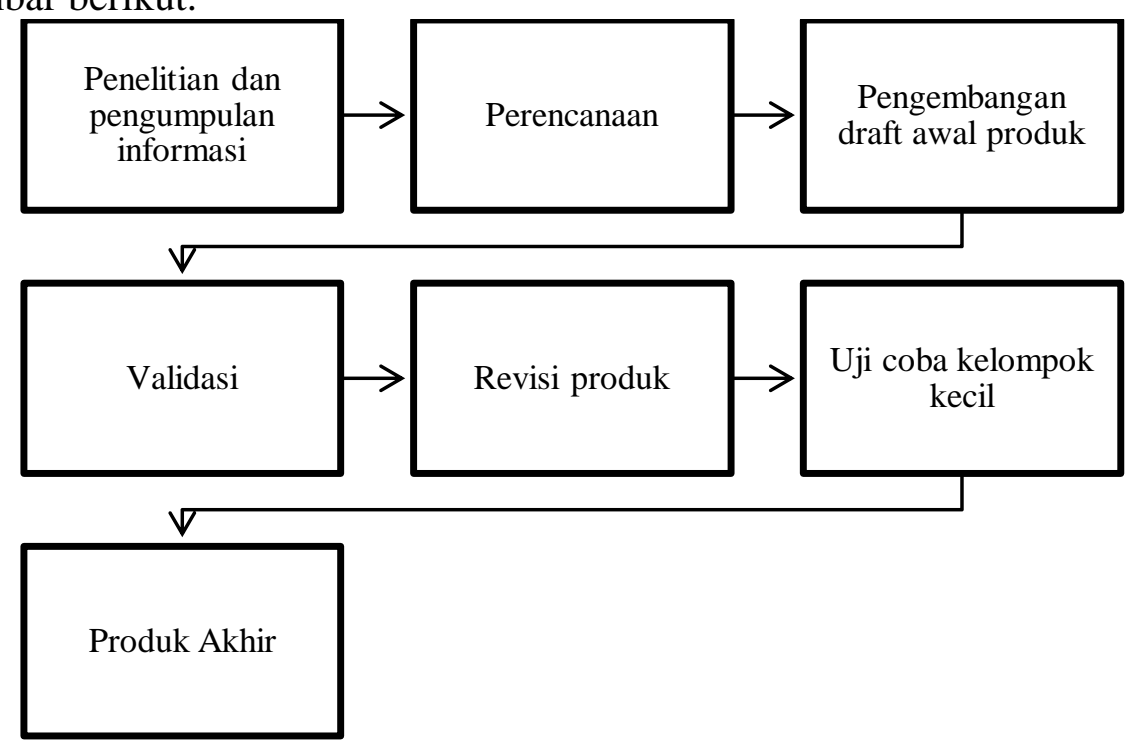

Gambar 3.1 Langkah-langkah Pengembangan Model Borg dan Gall Termodifikasi (1983)

Prosedur pelaksanaan yang dilakukan adalah sebagai berikut.

a. Penelitian dan pengumpulan informasi dilakukan dengan melakukan studi pustaka, observasi lapangan serta wawancara. Studi pustaka dilakukan untuk memperoleh informasi dari buku atau referensi lain terkait materi dalam bahan ajar. Observasi dilakukan di Pantai Prigi dalam 2 sesi. Sesi pertama dilakukan pada pukul 07.00-12.00, sedangkan sesi kedua dilakukan pukul 13.00-17.30. masing-masing sesi obsevasi menunjukkan tahapan yang dilakukan nelayan mulai dari menebar jaring hingga menariknya ke daratan. Wawancara dilakukan dengan metode in depth interview pada nelayan Jaring Tarik.

b. Perencanaan dilakukan dengan membuat kerangka draft produk awal yang terdiri dari sampul, kata pengantar, daftar isi, bab 1 sumber daya laut Indonesia, bab 2 permasalahan sumber daya laut Indonesia, bab 3 pengelolaan sumber daya laut berkelanjutan, bab 4 kearifan lokal jaring tarik, dan daftar pustaka.

c. Pengembangan draft produk awal dilakukan dengan penyusunan suplemen bahan ajar digital. Penyusunan dimulai dari menulis draft dalam format document yang selanjutnya diubah ke format pdf. Draft tersebut diubah dalam format flip book dengan aplikasi 3D Pageflip Pro.

d. Validasi produk dilakukan ahli materi, bahasa, dan desain. Validasi dilakukan dengan pengisian angket oleh validator.

e. Revisi produk dilakukan berdasarkan hasil validasi.

f. Uji coba kelompok kecil dilakukan pada subjek uji coba yaitu siswa kelas XI IPS sebanyak 30 orang guna mengetahui keterbacaan produk. Subjek uji coba juga akan mengisi angket terkait produk. 
Jurnal Pendidikan Geografi:

Kajian, Teori, dan Praktik dalam Bidang Pendidikan dan Ilmu Geografi

Tahun 23, Nomor 2, Jun 2018 , Hal 78-84

g. Berdasarkan hasil uju coba kelompok kecil produk tidak perlu direvisi, sehingga produk yang diuji cobakan merupakan produk akhir.

Teknik yang digunakan dalam analisis data adalah deskriptif presentase. Teknik ini digunakan untuk mengolah data hasil angket yang diberikan pada validator dan subjek uji coba kelompok kecil.

Rumus yang digunakan adalah rumus persentase menurut Sudijono (1998). Adapun rumus tersebut adalah sebagai berikut.

Keterangan:

$$
P=\frac{f}{N} x 100 \%
$$

$\mathrm{P}=$ Presentase

$\mathrm{F}=$ Jumlah nilai angket

$\mathrm{N}=$ Jumlah nilai maksimal

Untuk mempermudah penafsiran terhadap hasil analisis persentase digunakan klasifikasi sebagaimana pada tabel berikut.

Tabel 2.1 Klasifikasi Presentase (Arikunto, 1998)

\begin{tabular}{llll}
\hline No & Presentase & Kriteria & Keterangan \\
\hline 1 & $76-100 \%$ & Layak & Tidak perlu revisi \\
2 & $56-75 \%$ & Cukup Layak & Revisi \\
3 & $40-55 \%$ & Kurang Layak & Revisi \\
4 & $>40 \%$ & Tidak Layak & Revisi \\
\hline
\end{tabular}

\section{HASIL DAN PEMBAHASAN}

\section{Penelitian dan Pengumpulan Informasi}

Penelitian lapangan dilakukan di Pantai Prigi. Penelitian lapangan dilakukan melalui observasi dan wawancara. Hasil observasi berupa dokumentasi dalam bentuk foto dan video, sedangkan wawancara menghasilkan diskripsi mengenai jaring tarik.

\section{Kearifan Lokal Jaring Tarik}

Jaring Tarik merupakan cara tradisional bagi nelayan Prigi untuk menangkap ikan. Jaring Tarik termasuk kearifan lokal masyarakat nelayan Prigi karena di dalamnya terkandung seperangkat aturan mengenai tata cara menangkap ikan secara tradisional. Sebagaimana disebutkan oleh Zulkarnain, Agustar, dan Febriamansyah (2008), kearifan lokal adalah berupa prinsip-prinsip, nilai dan cara tertentu yang dianut, dipahami, dan diaplikasikan oleh masyarakat lokal dalam berinteraksi dan berinterelasi dengan lingkungannya. Kearifan lokal tersebut diturunkan turun-temurun secara lisan dari generasi ke generasi, oleh karena itu nilai-nilai yang ada tidak tertulis.

Secara historis, kearifan lokal merupakan bentuk belajar nenek moyang dalam berinteraksi dengan lingkungan alam. Kehidupan masa lalu di mana manusia masih bergatung pada alam menjadikan nenek moyang belajar beretika yang baik agar dapat hidup rukun dengan lingkungan alam. Sebagaimana disebutkan oleh Kongprasertamorn (2007) penerapan tradisi kearifan lokal untuk mengelola sumber daya alam telah memungkinkan 
manusia untuk hidup dalam harmoni dengan alam untuk waktu yang lama. Oleh karena itu, nilai-nilai yang terkandung dalam kearifan lokal senantiasa ramah terhadap lingkungan alam.

Dalam kearifan lokal Jaring Tarik nilai-nilai yang bertujuan untuk menjaga sumber daya laut berbentuk karena keterbatasan kemampuan perlengkapan dalam menghadapi dinamika kondisi alam yang tidak menguntungkan. Misalnya saja saat arus bawah permukaan bergerak dari tepi menuju tengah laut maka penebaran jaring ditunda dulu. Hal ini dikarenakan arus bawah permukaan tadi membawa ikan menuju tengah sedangkan jaring berada di tepi, bila jaring tetap ditebar maka ikan yang ditangkap jumlahnya sedikit atau tidak dapat sama sekali. Hal ini berlaku juga saat ikan melakukan migrasi ataupun karena aktifitas pasang surut yang membawa makanan dan telur ikan.

Jaring Tarik juga didesain dengan jaring berbagai ukuran. Bagian terkecil dari jaring itu dapat meloloskan anak-anak ikan, sehingga yang tertangkap dalam jaring hanya ikan dewasa. Lubang jaring ada yang berukuran 4 jari orang dewasa, kemudian 3-2 jari orang dewasa (gembungan), dan kondongan 1 jari orang dewasa.

Keadaan seperti yang dijelaskan di atas dari segi ekonomi tidak menguntungkan. Tetapi dari aspek lingkungan itu merupakan hal yang baik karena memberikan waktu bagi ikan untuk berregenerasi. Dengan demikan sumber daya ikan tetap dapat terjaga keberlangsungannya.

\section{Pengembangan Produk}

Suplemen Bahan Ajar Digital

Suplemen bahan ajar digital yang dikembangkan memuat kearifan lokal dalam pemanfaatan sumber daya laut. Suplemen bahan ajar ini diharapkan mampu menjaga kelestarian sumber daya laut melalui pelestarian kearifan lokal yang ada.

Suplemen bahan ajar ini disusun dengan menggunakan software 3D PageFlip Pro. Materi bahan ajar diimpor ke 3D PageFlip Pro dalam bentuk PDF sebanyak 100 halaman. Selanjutnya dilakukan editing. Ekstensi luaran dari bahan ajar berupa EXE dengan ukuran $500 \mathrm{MB}$.

Suplemen bahan ajar digital yang dikembangkan memiliki kelebihan untuk menampilkan suplemen bahan ajar digital layaknya buku pada umumnya karena halaman buku dapat dibalik. Selain juga dilengkapi gambar, suara dan video. Hal ini bertujuan untuk memantapkan pemahaman pembaca.

Dalam suplemen bahan ajar termuat 4 bab. Bab 1 sumber daya laut Indonesia, bab 2 permasalahan sumber daya laut Indonesia, bab 3 pengelolaan sumber daya laut berkelanjutan, bab 4 kearifan lokal Jaring Tarik. Bab 1 pada suplemen bahan ajar ini membahas ragam sumber daya laut di Indonesia. Bab 2 membahas permasalahan sumber daya laut akibat pengelolaan yang tidak ramah lingkungan. Bab 3 membahas pengelolaan sumber daya laut yang tidak menyebabkan kerusakan, sehingga sumber daya laut dapat dimanfaatkan secara berkelanjutan. Bab 4 merupakan inti suplemen bahan ajar ini. Bab ini memuat materi pengelolaan sumber daya laut berbasis kearifan lokal Jaring Tarik.

\section{Validasi Suplemen Bahan Ajar Digital}

Validasi dilakukan oleh 3 ahli, yaitu ahli materi, desain dan bahasa. Para ahli melakukan penilaian dengan mengisi angket. Hasil validasi tiap ahli tersaji dalam tabel berikut. 
Jurnal Pendidikan Geografi:

Kajian, Teori, dan Praktik dalam Bidang Pendidikan dan Ilmu Geografi

Tahun 23, Nomor 2, Jun 2018 , Hal 78-84

Tabel 3.1 Hasil Validasi

\begin{tabular}{cc}
\hline Ahli & Nilai \\
\hline Materi & $95 \%$ \\
Desain & $90 \%$ \\
Bahasa & $91,67 \%$ \\
\hline Rata-rata & $92,2 \%$ \\
\hline
\end{tabular}

Hasil validasi materi menunjukkan nilai $95 \%$. Berdasarkan hasil validasi, materi dalam suplemen bahan ajar telah sesuai dengan kebutuhan KD dan tujuan pembelajaran. Materi dalam bentuk konsep, fakta dan data disajiakan telah disajikan secara runtut dan mudah dipahami. Media dalam bentuk gambar dan video juga menunjang materi yang disajikan. Meski demikian materi tentang kearifan lokal perlu lebih ditonjolkan.

Hasil validasi desain menunjukkan nilai $90 \%$. Penggunaan jenis, warna dan ukuran huruf telah sesuai dan kontras terhadap background. Tata letak cukup proporsional. Penggunaan media gambar dan video cukup jelas untuk diamati.

Hasil validasi bahasa menunjukkan nilai 91,67\%. Bahasa dalam suplemen bahan ajar dinilai lugas dan komunikatif. Istilah yang digunakan baku dan struktur kalimat maupun paragraf yang efektif. Meski demikian ada beberapa ejaan yang perlu diperbaiki.

Rata-rata hasil validasi adalah 92,2\%. Hal ini menunjukkan bahwa suplemen bahan ajar digital layak untuk diuji cobakan.

\section{Uji Coba Kelompok Kecil}

Uji coba produk dilakukan guna mengetahui keterbacaan suplemen bahan ajar. Uji coba dilakukan di SMAN 1 Trenggalek dengan harapan agar generasi muda di Trenggalek dapat melestarikan kearifan lokal Jaring Tarik. Uji coba ini dilakukan pada 30 siswa. Subjek uji coba merupakan siswa kelas XI IPS. Hasil uji coba adalah sebagai berikut.

Tabel 3.2 Hasil Uji Coba

\begin{tabular}{lr}
\hline Subjek uji coba & 30 siswa \\
Nilai rata-rata total & $88,08 \%$ \\
Nilai rata-rata materi & $86,94 \%$ \\
Nilai rata-rata bahasa & $82,92 \%$ \\
Nilai rata-rata desain & $90,83 \%$ \\
\hline
\end{tabular}

Berdasarkan uji coba produk diperoleh hasil keterbacaan produk sebesar 88,08\% dengan kriteria layak. Nilai rata-rata komponen materi yang disajikan dalam produk adalah $86,94 \%$. Komponen bahasa memperoleh $82,92 \%$, sedangkan komponen desain memperoleh $90,83 \%$.

\section{KESIMPULAN}

Suplemen bahan ajar digital yang dikembangkan dinyatakan layak untuk digunakan dengan nilai rata-rata hasil validasi materi, desain dan bahasa serta uji coba sebesar $91,19 \%$. 
Jurnal Pendidikan Geografi:

Kajian, Teori, dan Praktik dalam Bidang Pendidikan dan Ilmu Geografi

Tahun 23, Nomor 2, Jun 2018 , Hal 78-84

\section{DAFTAR RUJUKAN}

Arikunto, S., (1998). Prosedur Penelitian Suatu Pendekatan Praktek. Jakarta: PT. Rineka. Cipta.

Borg, Walter R \& Gall, Meredith Damien. (1983). Educational Research: An Introduction. New York: Longman.

Darsono, Prapto. (1999). Pemanfaatan Sumber Daya Laut dan Implikasinya Bagi Masyarakat Nelayan. Oseana.24 (4): 1-9. Retrieved from http://www.oseanografi.lipi.go.id/sites/default/files/oseana_xxiv(4)1-9.pdf.

Kongprasertamorn, K. (2007). Lokal wisdom, Environmental Protection and Community Development: the Clam farmers in Tambon bangkhunsai, Phetchaburi province, Thailand. MANUSYA: Journal of Humanities, (Online),10 (1), Retrieved from http://www.manusya.journals.chula.ac.th/files/essay/Lokal\%20Wisdom\%20Environm ental\%20Protection.pdf

Kusumastanto, Tridoyo. (2003). Pengembangan Sumberdaya Kelautan dalam Memperkokoh Perekonomian Nasional Abad 21. Paper presented at The Seminar Pembangunan Hukum Nasional di Kuta, Bali, 14-18 Juli 2003.

Sholihin, dkk., (2013). Laut Indonesia dalam Krisis, Retrieved February 25, 2015, from website:

http://www.greenpeace.org/seasia/id/PageFiles/533771/Laut\%20Indonesia\%20dalam $\% 20$ Krisis.pdf).

Stanis, Stefanus. (2005). Pengelolaan Sumber Daya Pesisir dan Laut Melalui Pemberdayaan Kearifan Lokal di Kabupaten Lembata Propinsi Nusa Tenggara Timur. (Thesis). Semarang: PPs Universitas Diponegoro, Retrieved February 25, 2015, from website: http://eprints.undip.ac.id/17932/1/STEFANUS_STANIS.pdf.

Sudijono, A. (1998). Pengantar Evaluasi Pendidikan. Jakarta: PT Raya Grafindo.

Sumarmi. (2012). Pengembangan Wilayah Berkelanjutan. Malang: Aditya Media Publishing.

Sumarmi. (2014). Pengelolaan Lingkungan Berbasis Kearifan Lokal. Malang: Aditya Media Publishing.

Zulkarnain, Agustar, Asdi dan Febriamansyah, Rudi. (2008). Kearifan Lokal Dalam Pemanfaatan dan Pelestarian Sumberdaya Pesisir (Studi Kasus di Desa Panglima Raja Kecamatan Concong Kabupaten Indragiri Hilir Propinsi Riau), Jurnal Agribisnis Kerakyatan, (Online), 1(1):69-84, retrived from https://ejournal.unri.ac.id/index.php/JT/article/view/241 